\title{
The Evolution of The Language from the Philosophers' Viewpoint
}

\author{
Ahmadova Khanim Salim ${ }^{1}$ \\ ${ }^{1}$ Khazar University, Baku, Azerbaijan \\ Correspondence: Ahmadova Khanim Salim, Khazar University, Baku, Azerbaijan. E-mail: \\ sahilamustafa@yahoo.com
}

Received: May 16, 2016 Accepted: July 3, 2016 Online Published: September 23, 2016

doi:10.5539/ijel.v6n5p201 URL: http://dx.doi.org/10.5539/ijel.v6n5p201

\begin{abstract}
The article investigates linguistic sources about the language which have been investigated by the linguists for many years. The author has been studying linguistic sources comprehensively since the time of V. fon Humboldt, F. de Saussure etc. The main purpose of the author is to search the essence of the language and try to find the answer of the question how the language was evoluated. The questions "how life began? how the universe began? and how the language evoluated?" are highlighted in the given article. The author gives explanation to two theories about the essence of the language. The first one is the theory about the essence of the language which is supported by N. Chomsky and his followers. The content of their theory is that the language is innate. N. Chomsky always emphasized that the language is at least as much a system structuring and thinking about the world as it is a vehicle for communication. Though some linguists don't agree with this idea. The second theory which is supported by a biologist Derek Bickerton and others is that the language is not innate. The author gives her comments on both of the theories. Sometimes one theory wins, sometimes the other one. But no concrete result has been found yet, either by linguists or by bilologist, etc.
\end{abstract}

Keywords: language, essence, meaning, speech, sentence, social, cognitive

\section{Introduction}

The evolution of the language has always interested the linguists. The investigations dealing with the evolution of the language have been under research since ancient times. The ancient Greeks considered the living beings to be social humans who are able to communicate with their homogenous. The development of philosophy and nature sciences caused the formation of many opinions about the essence of the language. Some consider the formation of the langauge with the nature, while others claim that it is the result of an unknown divine sources. It is clear that almost all animate organisms communicate with one another. For instance, fireflies flash, frogs croak, crickets or grasshoppers like rubbing their legs together, or against their wing cases, producing kinds of sound known as stridulations, birds perform songs of varying degrees of complexity, wolves howl, bees dance, and ants do it with chemistry. All of these tend us to think about the evolution of the language. Because of this reason the scientists beginnig from Saussure tried to study the origin of the language.

\section{Literature Review}

Searching the history of the linguistics it becomes clear that one of the main problems dealing with the essence of the language was investigated by Humboldt \& Saussure. Saussure stated the place of the language and he pointed out the new era in the linguistics. He wrote: "Language consists only some parts of the speech activities, but this is the main part" (Ferdinand, p. 66). Language can be used by any speaker and can be accepted by the collective community; it also realizes speech activities, the ability carrying functions. Generally, speech is an activity, and it is considered to be various and motley. It is able to spread to various branches and can act physically, physiologically and psychologically. It is individual as well as social. It cannot be referred to any life events of the humans because it is impossible to form the style of completeness here. Contrary, language is considered to be a complete substance (Ferdinand, p. 67).

Then Saussure stated that studying speech activities needed to have two parts. The first one is langauge which is considered to be a main part. The second one is speech, and this can be considered to be not so important as the first part. (Ferdinand, p. 67). Saussure considered the langauge to be social, not depending on the human, and it is fully physiological.

It is necessary to stress that Saussure's distinction between diachronic studies of language is the most significant 
one. It highlights the analysis of textual evidence for how languages change over time, and the synchronic study of language. Language is presupposed as a static, self-contained phenomenon at every historical point. Investigations show that synchronic study of language certainly already existed in Saussure's day. For instance, Saussure admired William Dwight Whitney's work. He recognized it as a counterpoint to the dominant comparative-historical school. Over time, valorization of synchronic study of language has had massive impact beyond linguistics, in the humanities, social sciences, even public life (Harris, pp. 194-213).

Yelmslev who referred Saussure's opinions of the language wrote: "The main service of Saussure is that he discovered the language. He discovered the language which helped men study human's behavior and also study the behavior of others" (Veyselli, p. 15). In 1953 Hyelmslev wrote "The Prolegomena to a Theory of Language" in Danish, and it was translated in English in 1953. The Prolegomena largely consists of a tissue of loosely connected conceptual statements couched in idiosyncratic terminology which offers no extended example of how glossematics might succed in the analysis of real language, nor a satisfying overview of how its parts cohere. Hjelmslev posthumously published Resume of a Theory of Language (1975). It displays Hjelmslev's penchant for eccentric technical vocabulary, but unfortunately does little to answer questions that the Prolegomena raises (p. 10).

Speaking about the language it is impossible to avoid mentioning the works of Humboldt dealing with the language. Some scientists consider his works about the language to be very uncommon. Humboldt accepted the importance of individual languages studying detailed empirically. In 1822 writing the letter to Shelegel he declared: "After investigating most of the sources about the evolution of the languages, I came to the conclusion that all languages share the same universal grammar". He also considered the language to have unlimited usage of limited means. This explanation means that the human's mind is not limited (Veyselli, p. 102). It is important to stress that Humboldt shared with Schlegel a conviction that inflecting languages confer special intellectual capacities. Our impression is that to Humboldt (as to many of his contemporaries), languages are not equal vehicle for intellectual development or expression. This belief implicates another basic Humboldtian theme- the relation of language, thought and culture. In the same 1822 lecture, he claimed that inflecting languages predispose their speakers to formal analysis (Humboldt, pp. 29-37).

One of the main figures in linguistics who had vast opinion about the evolution of the language is Noam Chomsky. Some scientists think that Chomsky has been the target of criticism for his opinions about the evolution of the language because he believes that human nature is largely determined by human culture. Some biologists such as Bickerton go up against Chomsky (Thomas, p. 249).

It is true that Chomsky hadn't said anything about the evolution of language for many years. In 1975 at a conference he was asked such a question how language got to be the way it was? His answer was the following:

Well, it seems to me that would be like asking the question, how does the heart get that way? I mean, we don't learn to have arms, we don't learn to have arms rather than wings. What is interesting to me is that the question should be asked. It seems to be a natural question; everyone asks it. And I think we should ask why people ask it. (Bickerton, p. 170)

The answer to this question can be considered to be verbatim. After this in 2002 a paper by Marc Hauser, Noam Chomsky \& Tecumseh Fitch appeared in the "Science's Compass" section of the prestigious journal Science. The title of the article was "The faculty of Language: What Is IT, Who has it, and how did it evolve?" It is important to mention that till then Hauser \& Chomsky had been on opposite sides of at least two of the most crucial issues that langauge evolution involved. Being a biologist Hauser supported the modern synthesis of neo-Darwinism. He considered the evolution from the selection and recombination of genetic diversity. Hauser wrote: "language, as good a trait as any, would therefore be viewed as a communicative form that evolved from earlier forms." (Bickerton, p. 172). The other biologist Richard Lewontin, Conrad Waddington, and some other biologists stated the importance of behaviour in evolution. Richard Dawkins anicipated certain aspects of the theory in his book called "The Extended Phenotype". He tried to state the concept of phenotype. Though he critisized the niche construction, he wrote that animal's genes included the artifacts that the animal constructed. He wrote that an animal's behaviour tends to maximize the survival of the genes for that behaviour. And this is true according to niche constructions.

Unlike Hauser, Chomsky claimed that "it is almost universally taken for granted that there exists a problem of explaining the evolution of human language from systems of animal communication." Basing on the ideas of Hauser about the ACS, he also added that studies of annimal communication only serve to indicate "the extend to which human language apears to be a unique phenomenon, without significant analogue in the animal world." He concluded that "it is quite senseless to raise the problem of explaining the evolution of human langauge from 
more primitive systems of communication." Hauser also supported the importance of natural selection in language evolution. He regarded that natural selection has the principle driving force in evolution generally and language evolution in particular. He concluded that "natural selection is the only mechanism that can account for the complex design features of a trait such as language."(Bickerton, p. 180)

Chomsky didn't support this idea. He argued against any role for natural selection in langauge evolution. Basing on different attributes of langauge, he claimed that "to attribute this development to 'natural selection' ... amounts to nothing more than a belief that there is some naturalistic explanation for these phenomena ... it is easy even to imagine a course of selection that might have given rise to them." (Bickerton, p. 173)

Hauser could maintain his belief in natural selection by locating all the components of language in species. Though Chomsky stopped insisting on the uniqueness of language as a whole, and the degree to which it was separated from the capacities of other species. He received confirmation of the special status of recursion as the central mechanism in syntax, and syntax was, of course, what he had always regared as the most essential component of language. He continued to assert that it had not been selected as a specific linguistic mechanism. This is his point that language hadn't been selected for qua language; it was just that a whole lot of things selected for other purposes had somehow conspired to produce language. Bickerton states that in order to make some compromise it is necessary to part the territory of language. Language can be officially divided into two parts: FLB, the faculty of language (broad sense), and FLN, the faculty of language (narrow sense), which formed a part of FLB. FLB dosen't include the "internal communication system", but it carries everything in language. FLN was the only part of FLB that was both (a) limited to humans and (b) specifically dedicated to language. The rest of FLB either had antecedents in other species or if, developed by humans, was initially developed for purposes other than purely linguistic ones. (Bickerton, p. 183)

\section{Analyses of Some Theoretical Sources}

Chomsky and his followers never liked natural selections. They claim that there are other factors in the evolution of the langauge. Especially, Chomsky claim that the evolution results from mysterious, yet-undiscovered laws of form, laws of development, or other similar factors.

The biologist D. Bickerton doesn't agree with Chomsky in this matter. He gave two evolutionary models side by side. His and Chomsky's:

\begin{tabular}{ll}
\hline Time1: Animals have concepts that won't werge. & Time1: Animals have concepts that won't merge. \\
\hline Time2: Protohumans start talkng. & Time2: Typically human concepts, which will merge, appear. \\
Time 3: Talking produces typically human concepts. & Time 3: The brain gets rewired. \\
Time 4:Merge appears and starts merging typically human concepts. & Time 4: Merge appears and starts merging typically human concepts. \\
Time 5: The brain maybe gets rewired (plausible but not certain). & Time 5: Capacities for complex thougt, planning, etc.develop. \\
Time 6: Capacities for complex thought, planning, etc develop. & Time 6. People start talking. \\
\hline
\end{tabular}

Stages don't differ substancially in their content, but the ordering of the stage is very different. The first important difference is that in the first model, one stage follows the next. One stage drives the next, each new development changing the selective pressure for the next. This is the way how evolution works. Now let us analyse Chomsky's model. The fact that draws our attenton is that the most important stages have no motivation at all. Nothing drives them. Chomsky's version of evolution does not interest anywhere with the realities of evolution. (Bickerton, p. 189)

The fact is obvious. Chmosky believes that human thinking came first and enabled langauge. Chomsky stopped insisting on the uniqueness of langauge as a whole, and the degree to which it was separated from the capacities of other species. He went on insisting that language hadn't been selected for qua language; it was just that a whole lot of things selected for other purposes had somehow conspired to produce langauge.

Unlike Chomsky D. Beckerton believes that language came first and enabled thinking. One or the other may be true. All need to be experimented. The role of brain is also very important in this case.

According to Gary Marcus of New York University, the brain takes information from the senses, analyzes that information, and translates it into commands that get sent back to the muscles." He states that brains were specifically built to do this function and it is sufficient for life on earth. He suggests that the brain does its job in a series of steps, along a one-way trajectory:

(1). Receive information from senses; 
(2). Send it to be analyzed for identification;

(3). Send an order to execute that action (Bickerton, p. 192).

As non-humans, namely animals cannot send to each other their thinkings; they cannot communicate with each other. They are able to communicate to each other only with their instincts. They do not carry the mind that humans have. Chomsky states that the differences between the brain of the humans and the brain of the animals are very obvious. The notion of animal "langauge" is only observed over the animals. The mind and the symbols of animals' language is absolutely different. It is necessary to state that Chomsky can state deep differences among the languages of animals and humans. He states that functional reference can be observed in the animal communication. He states that mind-independence-thinking can create a relation to the real world. Then Chomsky attracts attention to the peculiarities of the human's sound. He claims that human words are the only kind of unit that recursion can apply to. That is why when recursion appears these concepts have already been presented. This commits Chomsky to the following sequence of events:

Time 1: Animals have concepts that won't merge.

Time 2: Typically human concepts, which will merge, appear.

Time 3: The brain gets rewired.

Time 4: Merge appears and starts merging typically human concepts.

Time 5: Capacities for complex thought, planning, etc.develop.

Time 6: People start talking.

With this Chomsky seems to have solved the problem of evolution of the language. (Bickerton, p. 183)

Generally, according to Chomsky language had to evolve inside the organism before it could appear inside it.

William Calvin of the University of Washington pointed out that what happens in the brain resembles what happens in the singing of choirs. He compare it like this: If only five or six people sing together, you can tell very queckly if one of them is out of tune; if a choir of a hundred or more voices is singing, half a dozen could be out of tune and you'd never know. The variation between voices averages out, you hear only a single, seemingly seamless flow of sound (Bickerton, p. 185).

Brugmann is one of the linguists who was interested in the evolution of the language. Brugman asserted that language exists only as a human product, with "a true existence only in the individual". Language change is therefore due to change in speakers' language behaviour, not to the drift of language as an independent, external entity. Brugman also asserted that the forces acting on present-day speakers are the same as those that acted on speakers in the past (Thomas, p. 143). To Brugmann the correct way to understand langauge change admitted evidence from diversity of contemporary languages and dialects, not only reconstructed forms from earlier languages. Brugmann pointed out that the study of living languages can lead to the understanding of how langauges evolve. On the other hand he tried to explain linguistic change. In this he didn't go as far as Ferdinand in balancing the value of diachronic study of langauges (study of how languages change over time). (Thomas, $p$. 143)

John Locke can be called one of the most famous English philosophers who wrote philosophy and psychology of language. He asserted language as an instrument for communicating knowledge. He argued that to evade misunderstanding, complex ideas must be analysed into the simple, definable ideas out of which complex ideas are constructed. His most famous facet is that the mind is created as a blank slate, devoid of innate ideas, on which sensory experience is inscribed. It is important to state that this position implicates him in the controversy with Chomsky's historiography of linguistics. It contrasts he views of "rationalists" versus "empiricists" about the nature of mind and language. Locke argued that if principles are innate, the ideas out of which they are constructed are innate too. Then he pointed out that purportedly innate speculative and moral principles are not met in all human societies.

Some psychologists such as Spelke showed his attitude to Lock's principles. He argued that infants are born with elaborate, domain-specific cognitive resources; linguists such as Crain report experimental results that children possess intricate grammatical knowledge that they cannot have gleaned through experience. In this position they support Chomsky's conclusion that an innate human language faculty shapes children's emerging native-language grammars (Thomas, p. 70). It is important to state that N. Chomsky rarely adverts to Locke, even though Locke's essay is about anti-innatism. Chomsky attributes to Locke a position close to Descartes with respect to innatism. But he also hold the dychotomy between empiricists and rationalists. Some critics, such as Aarsleff agreed that Locke's anti-innatism has been misrepresented, but interpret this as a challenge to Chomsky's stark separation of 
empiricism from rationalism (Thomas, p. 70). It is necessary to state that J. Locke raised issues about the sources of linguistic and cognitive capacities that continue to animate scholarship in his own time.

One of the Azerbaijanian linguists Veysalli also investigated linguistic sources for showing his viewpoint about the evolution of the langauge. He considers the language to be mysterious and complex notion. Veysally claims that all concepts that humans use while expressing their languages are related with the mind. He points out that language is such a kind of relation it connects all individuals to each other; it is abstract and a social instrument (Veysalli, p. 100).

\section{Conclusion}

Language is a very complex and mysterious event. The investigations on the language prove that language doesn't have a definition that can be accepted by all, or it is impossible to form such a kind of definition. As it is stated above in different times various linguists investigated historical linguistic sources for to try to study the way of development of the evolution of the language. As the article writes there exist different kinds of opinions about the stated problem. But no exact answer has been found yet. We also tried to express our viewpoint about this problem though the exact answer to this problem cannot be given.

\section{References}

Bickerton, D. (2010). Adam's tongue (1st ed.). United States of America.

Ferdinand, de S. (2003). General Linguistics Course (translated from English by prof. Jafarov N. G). Bak1, BSU.

Harris, R. (2001). Saussure and his Interpreters. New York: New York University Press. http://dx.doi.org/10.3366/edinburgh/9780748613083.001.0001

Hjelmslev, L. (1961). Prolegomena to a theory of Language (2nd ed., F. J. Whitfield, trans.), University of Wisconsin Press, Madison, W1 (1st ed. 1953, Indiana University Publications in Antropology and Linguistics; original work published 1943).

Hjelmslev, L. (1975). Resume of a Theory of Language (F. J. Whitfield, ed. and trans.). University of Wisconsin Press, Madison, W1.

Humboldt, W. V. (1988). On Language: The Diversity of Human Language-Structure and Its Influence on the Mental Development of Mankind (P. Heath, trans.). Cambridge: Cambridge University Press (original work published in 1836).

Labov, W. (1994). Principles of Linguistic Change: Vol. 1. Internal Factors. Oxford: Blackwell.

Lyons, J. (2002). Linguistic Semantics. Cambridge University Press.

Marcus, G. (2004). The birth of the mind. New York: Basic Books.

Morpurgo, D. A. (1986). Karl Brugman and late nineteenth-century linguistics. In T. Bynon \& F. R. Palmer (Eds.), Studies in the History of Western Linguistics. Cambridge: Cambridge University Press.

Thomas, M. (2011). Fifty Key Thinkers on Language and Linguistics. London and New York: Routledge Taylor and Francis Group.

Veysalli, F. (2011). Introdcution to German Linguistics. Bak1: Mutarjim.

Veyselli, F. (2007). Language. Bakı: Education NPM.

\section{Copyrights}

Copyright for this article is retained by the author(s), with first publication rights granted to the journal.

This is an open-access article distributed under the terms and conditions of the Creative Commons Attribution license (http://creativecommons.org/licenses/by/4.0/). 